(c) A seminar of and by the faculty, each of whom would hold forth for one week. Selected students would be invited to participate in this seminar and others permitted to attend it.

I refrain from describing the contents of the above courses and seminars so that you may feel entirely free in your thinking on this subject.

8. The executive committee, in charge of the School, should represent various viewpoints, universities, and disciplines, and its membership should be rotated. An essential need is to assure by its constituency that every qualified scholar and every scholarly viewpoint will receive fair and equal treatment. This is not easy; but it can be done!

9. A test period of at least three years would be required. If, at the end of that experimental period, the School should be continued on a secure basis, certain other matters should be explored, especially concerning (a) publication, e.g., of faculty seminar reports and teaching materials, (b) the organization of cooperative research units, (c) the carry-over of projects beyond the summer session, and (d) perhaps eventually the organization of a national research institute.

10. What is the next step to be taken at this time? This is the question regarding which I am particularly in need of help. I am willing, without any additional commitment, to serve as a temporary post office and conduit for transmitting suggestions to interested persons.

Accordingly, I invite you to write me regarding the above proposals, setting forth your views and especially your suggestions regarding organization. Do you think that the proposal is feasible? What changes and additions to the above proposals do you suggest? Are you willing to participate in the project? Have you any suggestions regarding the financing of the School? Do you think that I should ask a few persons, representing different universities and disciplines, to meet as a temporary organizing committee? Whom do you suggest should be invited to serve in that capacity? What other suggestions do you have to offer?

I have tried in this letter to avoid even the suggestion of exhortation or salesmanship. Interested scholars will, I am confident, understand the needs and opportunities adverted to, without embellishment of any kind. I should have preferred to write a personal letter to you regarding the above matters, but there are obvious advantages in the method used, not least of which is that no one who is not greatly interested in the cultural study of law will feel under any obligation to reply. I hope I have made the proposal sufficiently clear to those who are seriously interested in the indicated objectives.

\section{Indiana University.}

Sincerely,

\section{APPOINTMENTS AND STAFF CHANGES}

Byron R. Abernethy has taken a year's leave from his position as professor of government at Texas Technological College to serve as regional director of the Wage Stabilization Board, Region 10, Dallas, Texas. 
Charles S. Ascher of Brooklyn College served during the past summer as consultant to the World Health Organization in Geneva, Switzerland, on problems of program development. He also attended the sessions of ECOSOC as representative of the International Institute of Administrative Sciences and the International Union of Local Authorities.

Francis R. Aumann is on leave from his position at Ohio State University and is serving as a visiting professor at the State University of Iowa.

Thomas S. Barclay is on leave from his position at Stanford University for the academic year 1951-52.

Frederick C. Barghoorn has been advanced to an associate professorship in political science at Yale University.

Jorge Basadre, Peruvian historian and one-time director of the Department of Cultural Affairs of the Pan American Union, is to be visiting professor of Latin American affairs in the Woodrow Wilson School of Foreign Affairs of the University of Virginia during the second semester of the academic year 1951-52 and during the summer session of 1952 . His appointment at the University of Virginia has been made possible by a grant from the Henry L. and Grace Doherty Charitable Foundation.

William M. Beany, Jr., instructor in politics at Princeton University, spent the past summer in field research under a grant from the Princeton University Research Committee for a study of certain selected judicial practices.

Robert $P$. Benedict is serving as acting head of the department of government at Boston University during the absence of Professor Lashley G. Harvey.

LeRoy Bennett, assistant professor of political science and public administration at Michigan State College, has received a Ford Foundation grant for a study of the United Nations which he is currently conducting.

Frank Blackford, formerly a teaching fellow in political science at Michigan State College, has been appointed administrative assistant to the governor of Michigan.

William J. Block, recently a graduate student at the University of Mllinois, has accepted an appointment at The Citadel.

George F. Brasington, recently a graduate student at the University of Illinois, has been appointed to an instructorship in the department of political science of Emory University.

Gary Brazier has been appointed to an instructorship at Ohio State University.

Henry L. Bretton, formerly a predoctoral instructor at the University of Michigan, has been appointed to a regular instructorship at that University. 
John E. Brigante has resigned from his position at Boston University to become director of the Boston Office of Price Stabilization.

Philip W. Buck will be on leave from Stanford University from January to October, 1952, for research in Great Britain on methods of economic planning there.

Eugene Burdick (Lieut. Comdr., USNR), who in civilian life is assistant professor of political science at the University of California (Berkeley), is serving as academic consultant for an advanced course in strategy and sea power which has recently been organized at the Naval War College, Newport, Rhode Island.

James M. Burns has been named chairman of the department of political science at Williams College.

James L. Busey, assistant professor of political science at the University of Wyoming, taught during the first term of the summer quarter of 1951 at New Mexico Highlands University.

I. L. Claude has been granted a year's leave of absence from his position as assistant professor at Harvard University in order that he might accept a Ford Foundation fellowship.

Gordon B. Cleveland, instructor in political science at the University of North Carolina, has received a grant from the Ford Foundation to explore the experiments under way to improve the teaching of the basic course in American government. He will make his headquarters at Syracuse University, but will visit several eastern universities to examine their methods of teaching the course.

Morris $\mathrm{H}$. Cohen, assistant professor of government at Clark University, received a faculty fellowship from the Ford Foundation for the academic year 1951-52. His plans for the year include service as intern in several government offices in Washington, D. C.

Francis W. Coker, professor emeritus of Yale University, is serving as lecturer at that institution for the academic year 1951-52.

O. B. Conaway has been named assistant director of the Bureau of Public Administration at Boston University. He will have charge of this Bureau and of the Institute of Public Service at Boston University during the absence of Professor Lashley G. Harvey.

Harry Rex Davis has been advanced to the rank of assistant professor at Beloit College.

Robert G. Dixon, Jr., has taken a year's leave from his position as assistant professor of government and politics at the University of Maryland to study law at Stanford University under a Ford Foundation grant. 
William F. Dowling, Jr., is serving as an instructor in government at Clark University for the academic year 1951-52, in the absence of Assistant Professor Morris H. Cohen.

Alex N. Dragnich is serving as acting head of the department of political science at Vanderbilt University.

William Ebenstein of Princeton University was a visiting professor at the University of Pennsylvania during the summer of 1951.

N. Marbury Efimenco has been advanced to an assistant professorship at the University of Michigan.

John Ericksen, recently of the University of Minnesota, has been appointed to an instructorship at the University of Oklahoma.

Alfred P. Fernbach has returned to his position as associate professor in the Woodrow Wilson School of Foreign Affairs of the University of Virginia after a year's leave spent in Europe and England on a Fulbright research grant.

Wesley Fishel, formerly of the University of California (Los Angeles), has been appointed as an assistant professor of political science and public administration at Michigan State College.

Michael Flach is serving as a visiting lecturer in political science at the University of Oregon.

Ossip K. Flechtheim, associate professor of government and history at Colby College, is serving as visiting professor in the law faculty of the Free University at Berlin. He is also lecturing at the Hochschule fuer Politik in Berlin during the winter term of 1951-52.

D. F. Fleming has resigned from the chairmanship of the department of political science of Vanderbilt University and has been appointed to a research professorship.

John L. Fletcher, Jr., has been appointed to an instructorship in government at Boston University for the academic year 1951-52.

Peter J. Fliess, assistant professor at Louisiana State University, has been granted a leave of absence to enable him to accept a Ford Foundation fellowship for the improvement of teaching. He will visit a number of eastern universities with a view to studying the improvement of the content of courses in international law and relations.

Guy Fox has been granted a year's leave of absence from his position as associate professor of political science and public administration at Michigan State College to enable him to teach at the University of Ryukyus in Okinawa and to advise the civil administration of the islands in matters of taxation and fiscal administration. 
J. Leiper Freeman, Jr., has been appointed research assistant with the rank of instructor at Princeton University. He will devote part of his time to teaching political science and part of his time to research on the Ford Foundation project on organizational behavior.

Louis L. Friedland has been promoted to an associate professorship in public administration at Wayne University.

Reed L. Frischknecht has been appointed to an instructorship in political science at the University of Utah.

Murray W. Fuller, a graduate of the City Manager Training Program of the University of Kansas, has been appointed city manager of Madison, South Dakota.

Oliver Garceau of Bennington College is serving as visiting professor at Williams College, and is also continuing his work at Bennington. At Williams College, he is teaching a course in political behavior jointly with Professor James M. Burns.

Herbert Garfinkel, formerly instructor at the Illinois Institute of Technology, has been appointed as instructor in the department of political science and public administration and as research associate in the Governmental Research Bureau of Michigan State College.

Frank Grace has been advanced to an assistant professorship at the University of Michigan.

George A. Graham of Princeton University acted as consultant to the Subcommittee on Ethics of the United States Senate Committee on Labor and Welfare during the summer of 1951.

Daniel R. Grant has been granted a partial leave of absence by Vanderbilt University to enable him to serve as assistant director of the Community Services Commission for Davidson County and the City of Nashville, Tennessee. The Community Services Commission is a temporary agency which is charged with the duty of making proposals for the readjustment of metropolitan intergovernmental relations and services in the Nashville area.

W. Brooke Graves will be a visiting professor of public administration at Florida State University during the second semester of the academic year 1951-52.

Fred Greene has been appointed to an assistant professorship in political science at Williams College.

Lee S. Greene has been granted a year's leave of absence from his position as professor and head of the department of political science of the University of Tennessee and has been appointed executive director of the Community Services Commission for Davidson County and the City of Nashville, Tennessee. 
Alan P. Grimes has been advanced to an associate professorship in political science and public administration at Michigan State College.

Heinz Guradze is teaching comparative government and international organization in the winter semester at the University of Cologne, after having taught at the same University during the past summer.

Andrew Gyorgy of Louisiana State University has been granted a leave of absence from that institution to enable him to accept a research appointment at Yale University.

Thomas T. Hammond has been granted a year's leave from his position as assistant professor in the Woodrow Wilson School of Foreign Affairs of the University of Virginia.

Lashley G. Harvey has taken a year's leave from his position as chairman of the department of government at Boston University and is at the London School of Economics under a Fulbright grant.

Ferrel Heady has been advanced to an associate professorship at the University of Michigan.

Dell G. Hitchner has been advanced to an associate professorship at the University of Washington.

C. Leonard Hoag is on leave from his position as associate professor of political science at Middlebury College and is serving as foreign affairs specialist in the Division of Public Studies, Office of Public Affairs, United States Department of State.

John P. Horlacher is on leave from his position as associate professor of political science at the University of Pennsylvania to serve as head of the Philadelphia regional office of the Wage Stabilization Board.

Robert Horn of the University of Chicago has been recalled to active duty in the United States Army. He is serving with the First Radio Broadcasting and Leaflet Group.

Schuyler Dean Hoslett has been advanced to an associate professorship and named assistant dean of the School of Business and Public Administration at Cornell University.

H. B. Jacobini has been appointed to an assistant professorship at the Huntsville Center of the University of Alabama.

Harry V. Jaffa, recently of the University of Chicago, has been appointed to an assistant professorship at Ohio State University.

Donald B. Johnson, recently a graduate student at the University of Illinois, has accepted an appointment at Iowa State University.

Richard B. Johnson, assistant professor at Tufts College, is teaching at the 
University of Maryland during the absence of Assistant Professor Robert G. Dixon, Jr.

Hattie M. Kawahara has been advanced to an assistant professorship at Wayne University.

Kazuo Kawai of the Nippon Times, Tokyo, Japan, has been appointed visiting lecturer at Ohio State University, after having served during the past summer as a visiting member of the political science staff of Stanford University.

Hans Kelsen of the University of California (Berkeley) was a visiting member of the faculty of the University of Washington during the summer of 1951.

David T. Kenney, recently a graduate student at the University of Illinois, has been appointed to an instructorship at Southern Illinois University.

Jarold A. Kieffer, formerly a member of the social science staff of the University of Minnesota, has joined the staff of the Office of Defense Mobilization in Washington, D. C.

Frank L. Klingberg has been advanced to a full professorship at Southern Illinois University.

Robert J. Koblitz, formerly an instructor at Harvard University, has been appointed to an assistant professorship at Bard College.

Morton J. Kroll has been appointed to an instructorship in political science at the University of Oregon.

Lynwood A. Lardner has resigned from his position as assistant professor of political science at Northwestern University to enter federal service.

Walter H. C. Laves, recently visiting professor at the University of Michigan, has been appointed consultant to the Economic Corporation Administration and is now giving full time to this agency.

K. C. Leebrick, who recently retired as professor of government, veterans' adviser and vice-president of the University of Hawaii, has been named assistant to the high commissioner of the Trust Territory of the Pacific. He is to be in charge of historical records and reports and is to assist the high commissioner in matters concerning the United States Department of State and the United Nations.

Nathan Leites of the Rand Corporation is serving as lecturer at Yale University for the academic year 1951-52.

Roy C. Macridis is on leave from Northwestern University for the academic year 1951-52 for work under a grant from the Ford Foundation.

M. Nelson McGeary of Pennsylvania State College taught during the past summer at the University of California (Los Angeles). 
Wiliam McIntosh, assistant professor of political science at Tennessee Agricultural and Industrial State College, spent the past summer in study and research at the University of Puerto Rico at Rio Piedras.

Alvin J. McNeil, recently a graduate student at Boston University, was a visiting instructor in political science at Florida Agricultural and Mechanical College during the summer session of 1951.

Boyd A. Martin, chairman of the department of social sciences of the University of Idaho, will be a visiting professor at Stanford University for the winter and spring quarters of 1952 to offer courses usually offered by Professor Thomas S. Barclay.

Henry L. Mason, formerly a graduate student at Columbia University, has been appointed as an assistant professor of government at Louisiana State University, where he will offer courses in comparative government and international relations.

Eugene Mawhinney, recently a graduate student at the University of Illinois, has accepted an appointment at Northeast Missouri State Teachers College.

Marvin Meade, a graduate of Fort Hays Kansas State College and the University of Kansas, has been appointed as a research assistant in the Bureau of Government Research of the last named institution.

James H. Meisel has been advanced to an associate professorship at the University of Michigan.

Charles A. Micaud has returned to his position as associate professor in the Woodrow Wilson School of Foreign Affairs of the University of Virginia aiter spending the first semester of the academic year 1951-52 in France for the Yale Institute of International Studies.

B. Mirkine-Guetzévitch recently returned to New York City after spending nearly six months in Europe. While in Europe, he taught at the Institute of Advanced International Studies of the University of Paris and the Ecole Nationale d'Administration, and delivered lectures at several other European universities.

Graeme C. Moodie, for the past two years a Commonwealth fellow at Princeton University, has returned to his post as lecturer at St. Andrews University, Scotland.

Robert J. Morgan, recently a graduate student at the University of Virginia, has been appointed to an assistant professorship at the University of Nebraska.

Ward M. Morton, associate professor at Southern Illinois University, has been recalled to active duty as a reserve air force officer.

Michel Mouskhely of the University of Strasbourg will be a visiting professor at Boston University during the second semester of 1951-52. 
Milton E. Muelder, professor and head of the department of political science and public administration at Michigan State College, has been named director of the Office of Research Development at that institution.

Frank Munk of Reed College served during the past summer as professor in charge of special courses in world political geography organized by the commanding general of the Fourth Air Force at the University of Portland for officer-instructors from air force reserve officer training corp units in seven western states.

James N. Murray, recently a graduate student at the University of Illinois, has accepted an appointment at Northwestern University.

Ivan Nagy is on leave from his position as assistant professor of political science at the University of Oregon for work under a grant from the Fund for the Advancement of Education of the Ford Foundation.

Felix Oppenheim of the University of Delaware is a visiting associate professor in the department of philosophy at Yale University during the present academic year. $\mathrm{He}$ is teaching ethics and political theory in Yale's program of directed studies.

R. Vance Presthus, formerly associate professor at the University of Southern California, has been appointed associate professor of political science and public administration at Michigan State College.

Eugene C. Price, formerly a graduate student at the University of Wisconsin, has been appointed as an instructor in the School of Public Administration of Florida State University.

William R. Pullen, recently a graduate student at the University of North Carolina, has been appointed assistant professor of political science at that University. He will be attached to the university library to organize and service the public documents section. The organization of the materials in this section is being facilitated by a grant from the Ford Foundation.

Maurice M. Ramsey has been advanced to an associate professorship in public administration at Wayne University. He is also serving as assistant to the dean of the Graduate School at that institution.

Ellsworth Raymond has been appointed as a lecturer in the department of government at New York University for the academic year 1951-52, where he is offering courses in Russian affairs.

Harry W. Reynolds, formerly of the Philadelphia Housing Authority, has been appointed as an instructor in political science at the University of Pennsylvania.

S. Grover Rich, Jr., has taken a year's leave from his position as assistant professor of political science at the University of Utah to accept a Ford Founda- 
tion fellowship. He is making Columbia University his headquarters, and is examining teaching methods and programs in the general field of international relations.

Fred W. Riggs, formerly research associate with the Foreign Policy Association, is serving in the New York office of the Public Administration Clearing House as assistant to Rowland A. Egger, associate director of the Clearing House.

Walter L. Riley has been named assistant dean of the College of Arts and Sciences of the University of Washington.

Benjamin Rivlin has returned to Brooklyn College after a semester's leave, during which he studied colonial problems in France and French North Africa under a travel grant from the Social Science Research Council.

Elston E. Roady has returned to Florida State University with the rank of assistant professor, following completion of his graduate studies at the University of Illinois.

Friedrich Roetter has been advanced to a full professorship in political science and economics at Upsala College.

Frank E. Rourke, a graduate student at the University of Minnesota, is serving as a part-time instructor at that institution for the academic year 1951-52.

Dankwart A. Rustow has taken a year's leave from his position as associate professor of political science at Oglethorpe University for work under a grant from the Fund for the Advancement of Education of the Ford Foundation. $\mathrm{He}$ is engaged in research on aims and methods of social science teaching.

Allan Saunders of the University of Hawaii is serving as visiting professor at Boston University for the academic year 1951-52.

James D. Schneider, a graduate of the University of Pennsylvania, was recently appointed personnel staff officer in the Division of Personnel, Tennessee Valley Authority, Knoxville, Tennessee.

John R. Scott, recently a graduate student at the University of Illinois, has been appointed headmaster of Onarga Military Academy in Illinois.

Samuel L. Sharp, associate professor at American University, is serving as visiting lecturer in foreign affairs in the Woodrow Wilson School of Foreign Affairs of the University of Virginia.

Ralph Smuckler has been appointed to an instructorship in political science and public administration at Michigan State College.

Albert Somit of New York University has been called to active duty in the United States Army as a reserve officer. 
Cummins E. Speakman, Jr., of the Woodrow Wilson School of Foreign Affairs of the University of Virginia has been appointed foreign student adviser at that University.

David Spitz is on leave from Ohio State University for work under a Ford Foundation grant.

T. Noel Stern of Boston University will be a visiting professor, under a Fubright grant, at the University of Strasbourg during the second semester of $1951-52$.

John O. Stitely is on leave from his position as assistant professor of political science at the University of Rhode Island to serve as executive aide to the governor of Rhode Island.

Ivan M. Stone has returned to his position at Beloit College after serving as a visiting expert in the United States Information Centers Program in Germany. While in Germany, he made a tour of Amerika Häuser, discussing various aspects of United States foreign policy. Earlier in the summer he delivered a series of lectures in England for the British United Nations Association.

Graham H. Stuart has returned to Stanford University after a sabbatical year spent in Europe. During his absence from Stanford he lectured at the Institut Universitaire de Hautes Etudes Internationales, Geneva, Switzerland; at the Salzburg Seminar in American Studies; and at the National War College in Washington, D.C.

Richard N. Swift has taken leave from his position at New York University to serve for a year as visiting lecturer in government at Harvard University.

Philip B. Taylor, formerly of Northwestern University, has been appointed as an instructor in political science at the University of Michigan.

Kenneth W. Thompson, formerly of Northwestern University, has been appointed to an assistant professorship at the University of Chicago, and he will participate in the program of the Center for the Study of American Foreign Policy of that University.

Harold T. Towe, a member of the political science staff of the University of Toledo and a lieutenant-colonel in the United States Army Reserves, was called to active duty on July 15,1951, as military government officer of the Second Army, Fort Meade, Maryland.

John E. Turner has been appointed to an instrustorship at the University of Minnesota.

Paul P. Van Riper is on leave from Northwestern University for the academic year 1951-52 to engage in research in administrative methods and procedures for the comptroller general of the Department of the Army.

John. P. Vloyantes has been appointed to an instructorship in political 
science at the University of Utah, following a year which he spent in Holland under a Fulbright grant.

Ralph M. Wade has been advanced to an associate professorship at the University of Wyoming.

Schuyler C. Wallace of Columbia University was a visiting member of the faculty of the University of Washington during the summer of 1951.

Robert E. Ward, assistant professor of political science at the University of Michigan, has been named assistant director of the Center for Japanese Studies at that University.

George A. Warp of the University of Minnesota is serving for a period of six months as consultant to the Public Administration Clearing House in Tokyo, Japan. He is advising the Clearing House on plans for a Public Administration Service, a project which is being financed by the Rockefeller Foundation.

Leo Weinstein has been appointed to an instructorship at the University of Chicago.

Norman Wengert has been granted a year's leave of absence from his position in the department of government of the City College of New York to enable him to undertake a special assignment in program management for the Program Staff, Office of the Secretary, United States Department of the Interior.

Allen S. Whiting, recently a graduate Student at Collimbia University, has been appointed to an instructorship at Northwestern University.

Kurt Wilk, associate professor of history and government at Wells College, taught at the University of Rochester during the summer of 1951.

Robert $R$. Wilson is on leave from Duke University to serve as a visiting professor at the University of Istanbul, Turkey, under a Fulbright grant.

Elaine Windrich has been appointed to an acting assistant professorship at Stanford University, where she will c.ier courses usually offered by Professor Philip W. Buck.

Raymond W. Young has been appointed as lecturer in the department of government of New York University for the academic year 1951-52.

Belle Zeller has been advanced to a full professorship at Brooklyn College.

\section{IN MEMORIAM}

While this issue was in press, news was received of the unexpected death of Frederic A. Ogg. His contributions to the AMErican POLITICal science Review have been summarized-to the extent that it is possible to summarize the devoted labor of twenty-four years-in Harold Zink's article on "The Growth of the american political science REviEw, 1926-1949," which appeared in the June, 1950, issue of this REview. The follow- 